\title{
Evaluation of Anatomy Course Teaching and Learning Outcomes for Iraqi Pharmacy Students: Internet-based Learning versus Blended Learning During the Pandemic
}

\author{
Sinan Subhi Farhan ${ }^{1 *}$, Ahmed Al-Imam $^{2,3,4}$, Marek A. Motyka ${ }^{5}$ \\ ${ }^{1}$ Department of Anesthesia Techniques, College of Medical Science Technology, University of Mashreq, Baghdad, Iraq; \\ ${ }^{2}$ Department of Anatomy and Cellular Biology, College of Medicine, University of Baghdad, Baghdad, Iraq; ${ }^{3}$ Department of \\ Computer Science and Statistics, PUMS Doctoral School, Poznan University of Medical Sciences, Poznan, Poland; ${ }^{4}$ Alumni \\ Ambassador, Barts and The London School of Medicine and Dentistry, Queen Mary University of London, London, United \\ Kingdom; ${ }^{5}$ Department of Social Work, Institute of Sociological Sciences, University of Rzeszów, Rzeszów, Poland
}

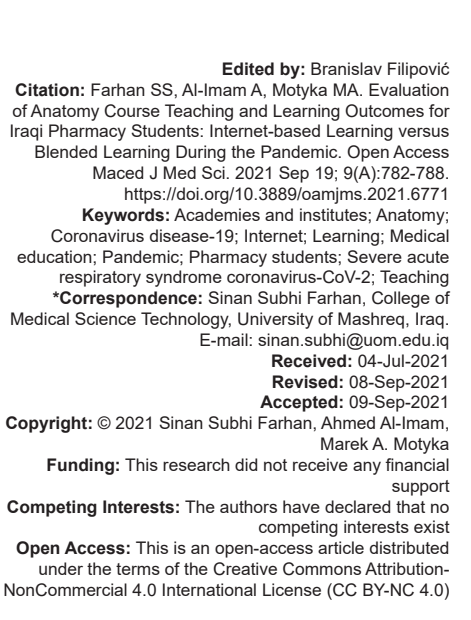

Abstract

BACKGROUND: Academic courses of human anatomy need to be reviewed periodically by students to ensure better learning outcomes, especially when the teaching process became internet-dependent during the pandemic.

AIM: Our study aims to explore pharmacy students' opinions concerning the theoretical and practical elements of the anatomy course taught in the College of Pharmacy at Al-Rafidain University.

MATERIALS AND METHODS: The ethical committee of the College of Pharmacy at Al-Rafidain University approved the study. We prepared a questionnaire (Cronbach's Alpha $=0.735$ ) to evaluate the positive and negative aspects of the teaching process. The questionnaire was presented as an online survey to pharmacy students $(n=305)$ who finished their anatomy course in two learning modalities, Internet-based learning $\left(n_{1}=105,34.43 \%\right)$ and blended learning (BL) $\left(\mathrm{n}_{2}=200,65.57 \%\right)$.

RESULTS: Participants of both groups were satisfied with the syllabus, using internet-based materials, and problembased learning concerning the theoretical aspect of the course. Concerning practical knowledge, both groups preferred using cadavers instead of dummies, and they verified the beneficial effect of online educational materials and computer-based applications. Pharmacy students demanded more than one anatomy course, while students from the BL group considered the anatomy course duration insufficient. Concerning the practical knowledge, students' marks were superior for students using BL, and the opposite was the case with theoretical knowledge.

CONCLUSIONS: BL is favored by Iraqi undergraduate pharmacy students; perhaps, it is attributed to the lively interaction between students and the teaching staff. We conclude that internet resources can be supportive of the classical teaching of anatomy.

\section{Introduction}

Human anatomy is an essential basic medical science; it has importance formedical and paramedical students, including pharmacy students [1]. Sound knowledge of Anatomy is mandatory for pharmacists due to their critical role in decision-making within clinical and healthcare institutes [2]. Teaching human anatomy for undergraduate pharmacy students can be a standalone educational program or integrated with histology or physiology courses [3]. Human anatomy is not only merely about knowledge of anatomical structures but also its profound relevance to medical practice, clinical studies, and health-care research [4]. Internationally, medical schools perpetually audit and revise their curriculum and educational methods, albeit the profound organizational and economic challenges, to achieve better learning outcomes and satisfaction among their students [5].

Before the pandemic, the Internet was an auxiliary learning tool in teaching human anatomy and anatomical sciences [6], [7], [8], [9]. The coronavirus disease 2019, responsible for the severe acute respiratory syndrome coronavirus 2 (SARS-CoV-2), imposed novel restrictions on social norms and dayto-day activities, including education, and resulted in unprecedented anomie of the social structure [10]. In 1938, Robert King Merton defined social anomie as a process occurring in societies that, due to sudden dynamic changes, deprive the members of a given community of the possibility of realizing culturally imposed goals (e.g., education, development, and self-determination) by means hitherto accepted [11]. During the changes taking place (caused, for example, by an economic crisis, war, ecological disaster, and pandemic), people must adapt to new conditions to 
achieve socially accepted goals; however, they do it, having at their disposal completely different possibilities of achieving them. They then "activate" new ways of adapting to new circumstances [10], [11].

Merton listed five such ways, only one of which (conformism) means accepting both new goals and new possibilities of achieving them; the others, including innovation, ritualism, rebellion, and escape, are actions in which either the goals or the means of achieving them, or both, are not accepted [10]. These actions may give rise to deviant behavior, which, according to this theory, is a "normal" reaction to anomic states (chaos, feelings of confusion, helplessness, existential anxiety) for those who engage in such behavior; some of these states may be unconscious so to speak, "forcing" the activation of psychological defense mechanisms that impede the correct assessment of the situation [12].

The need for auditing and reviewing educational programs of human anatomy, as a core basic medical science, has been carried worldwide, including in Japan (Rao and Rao, 2009), Italy (Snelgrove et al., 2009), Sweden (Edgren et al., 2010), and Korea (Kim and Kee, 2010) [13], [14], [15], [16]. In 2019, Ngan and colleagues found that blended learning (BL), implementing a combination of traditional and online (virtual) learning, is preferable by students [17]. Distancelearning and on-campus human anatomy programs were already conducted successfully for pharmacy students [18]. At the faculty of pharmacy (Al-Rafidain University, Iraq), the duration of the human anatomy course is 16 weeks for the theoretical and practical teaching; anatomy instructors convey both as a single course. The practical course has only one weekly credit hour, using anatomical dummies rather than cadavers. In the last few years, assisted technology relying on websites of the world wide web, including YouTube, and computer-based applications, had a growing role in teaching human anatomy. Therefore, educational institutes adopted BL globally; however, this year, strict Internet-based learning (IBL) was approved by the Iraqi Ministry of Health due to the emerging pandemic event.

Our study aims to explore the opinions of pharmacy students concerning the theoretical and practical elements of the anatomy course taught at the College of Pharmacy (Al-Rafidain University, Iraq). Accordingly, we conducted a survey regarding the two modalities of learning anatomy, blended versus Internet-based, to evaluate the theoretical basis, practical aspects, and the learning outcomes of the educational process.

\section{Materials and Methods}

Using a questionnaire, we conducted an online survey from June to September 2020 among
305 ( $n=305$ ) undergraduate students from the College of Pharmacy at Al-Rafidain University. We divided the participants into two groups; 200 students $\left(n_{1}=200,65.57 \%\right)$ who passed the course using BL and 105 students $\left(n_{2}=105,34.43 \%\right)$ who passed the course using IBL. The ethical committee of the College of Pharmacy at Al-Rafidain University approved the study. We distributed the electronic form of the questionnaire via the Google Classroom platform.

The study followed strict inclusion and exclusion criteria; only Iraqi students who were undergraduates, including males and females, from the faculty of pharmacy were allowed to access the survey based on their student ID number; hence, duplicate answers were prohibited. Nevertheless, we implemented a convenience sampling method due to the inherent nature of the online survey tool. Missing data were neglected, i.e., not included in subsequent data analyses.

The questionnaire had three main sections. The first section had yes (or) no questions, while the second one had a five-level Likert scale (strongly disagree, disagree, neither agree nor disagree, agree, and strongly agree); the third section had multiplechoice questions. We circulated the online survey, implementing three types of questions, including yes (or) no questions, 5-point Likert scale, and Multiplechoice questions. We also incorporated an additional aspect to survey the learning outcome, i.e. students' marks in practical and theoretical exams.

We conducted an internal consistency analysis concerning the questionnaire's validity and found that it had good reliability (Cronbach's Alpha $=0.735$, Standardized Cronbach's Alpha $=0.721$ ). Further, each of the three sections of the questionnaire had strong internal consistency (Cronbach's Alpha > 0.7). We processed raw data gathered by the survey tool using IBM-SPSS version 26 and Microsoft Excel 2016 with Analysis ToolPak add-in. We implemented Fisher's exact test, Mann-Whitney $U$ test, and the independent Student's t-test. Given the sample size, we deployed an alpha $(\alpha)$ value of 0.05 , i.e. $95 \%$ confidence interval.

\section{Results}

Concerning the theoretical teaching of anatomy (Table 1), the majority of the IBL group (85.7\%) and the BL group $(71.5 \%)$ showed their satisfaction with the curriculum ( $p=0.003$ ). Students from the BL group $(67.5 \%)$ declared that the anatomy course duration was insufficient compared to the IBL group (40\%); the difference was statistically significant ( $p=0.0001)$. Students from both groups preferred BL over IBL at $61.5 \%$ and $64.7 \%$, respectively; however, no significant difference existed between the two groups. Further, 
both groups favored problem-based learning, at $91 \%$ and $88.5 \%$, respectively. Statistically significant differences existed regarding the satisfaction with the syllabus and the course duration $(p<0.001$ and $<0.001$, respectively).

Table 1: First section of the survey: Questions with Yes or No

\begin{tabular}{|c|c|c|c|c|c|}
\hline \multirow[t]{2}{*}{ Question } & \multicolumn{2}{|l|}{ Blended } & \multicolumn{2}{|l|}{ Internet } & \multirow{2}{*}{$\begin{array}{l}\text { Fisher's exact } \\
\text { test ( } p \text {-value) }\end{array}$} \\
\hline & Yes (\%) & No (\%) & Yes (\%) & No (\%) & \\
\hline $\begin{array}{l}\text { Satisfied with the syllabus of } \\
\text { the anatomy course? }\end{array}$ & 71.5 & 28.5 & 85.7 & 14.5 & $0.003^{*}$ \\
\hline $\begin{array}{l}\text { The anatomy course } \\
\text { duration is sufficient? }\end{array}$ & 32.5 & 67.5 & 60 & 40 & $0.0001^{*}$ \\
\hline $\begin{array}{l}\text { Prefer blended over internet } \\
\text { learning? }\end{array}$ & 61.5 & 38.5 & 64.7 & 35.3 & 0.33 \\
\hline $\begin{array}{l}\text { Prefer to use problem-based } \\
\text { learning? }\end{array}$ & 91 & 20.4 & 88.5 & 11.5 & 0.31 \\
\hline
\end{tabular}

learning?

Concerning the practical teaching of anatomy (Table 2), students from the BL group showed that $44.5 \%$ agreed and $28 \%$ strongly agreed, preferring the use of cadavers instead of anatomical dummies, compared to $24.8 \%$ who agreed and $51.4 \%$ who strongly agreed from IBL group $(p=0.001)$. BL and IBL students agreed $(44.5 \%$ vs. $32 \%)$ and strongly agreed ( $42 \%$ vs. $68 \%)$ to incorporate the use of illustrative anatomical movies from websites, including YouTube, in addition to threedimensional computer and mobile-based applications $(p<0.001)$. A higher percentage of BL students were not satisfied with the weekly credit hours of the anatomy laboratory $(p<0.001)$. Students from both groups confirmed (strongly disagreed) the insufficiency of the course duration ( $37.5 \%$ vs. $33.3, p=0.043$ ). Participants from both groups showed similar results related to satisfaction with the laboratory teaching staff $(p=0.984)$. BL Students preferred small-group teaching $(p=0.004)$.

The third part of the questionnaire surveyed specific preferences by the participants (Table 3). Concerning the favorite anatomy subject, the highest percentage of $\mathrm{BL}$ students $(32.8 \%)$ favored the cardiovascular system, while the nervous system (neuroanatomy) had the lowest percentage (11\%). IBL group participants had a similar opinion; $38.1 \%$ favored the cardiovascular system, while the urogenital system had the lowest interest among IBL students $(1.9 \%)$. Contrary to BL students, almost onethird of IBL students (36.2\%) showed interest in studying neuroanatomy. Another topic is the number of courses required to study the anatomy curriculum effectively; both $\mathrm{BL}$ and $\mathrm{IBL}$ groups suggested undertaking two courses at $44.5 \%$ versus $58.1 \%$, respectively. Only a minority of students declared that they mandate four courses, at $16.5 \%$ and $11.3 \%$, respectively.

We also evaluated the learning outcome by comparing the students' final marks in the theoretical and practical exams (Table 4). Concerning the practical knowledge of anatomy, BL students achieved higher scores than IBL students (74.7 vs. $65.5, p=0.881$ ). On the contrary, IBL students had higher marks concerning the theoretical knowledge of anatomy $(72.1 \%$ vs. $66.2 \%, p=0.011)$. Nevertheless, none of these results was statistically significant.

To summarize, the students favored BL (Table 5). However, BL students mandated a longer course duration, needed more weekly hours for the practical teaching, preferred to study anatomy in two courses, and found the cardiovascular system was the most interesting to study.

\section{Discussion}

Our study is the first to evaluate anatomy course teaching among undergraduate pharmacy students from Iraq. We distributed the survey via Google Classroom virtual platform to assess the effectiveness of teaching the human anatomy course instructed for pharmacy students. We opine that students who learn human anatomy potently are more capable to efficiently comprehend related medical subjects, including physiology, pathology, and pharmacology.

Researchers conducted several studies on using the Internet as a supplementary teaching method; participants preferred adding additional Internet sources to traditional learning [6], [7], [8], [9]. In 2014, Hoffmann and Swailes studied integrated versus internet-based anatomy learning among dentistry students; however, they could not detect any statistically significant results [19]. In 2019, Singh and coworkers evaluated students connected with a single system, the muscular system; they found that an integrated learning modality was effective [20].

Table 2: Second section of the survey: Five-point likert scales for practical anatomy

\begin{tabular}{|c|c|c|c|c|c|c|c|}
\hline Question & Group & $\begin{array}{l}\text { Strongly } \\
\text { disagree(\%) }\end{array}$ & $\begin{array}{l}\text { Disagree } \\
(\%)\end{array}$ & $\begin{array}{l}\text { Neutral } \\
(\%)\end{array}$ & $\begin{array}{l}\text { Agree } \\
(\%)\end{array}$ & $\begin{array}{l}\text { Strongly } \\
\text { Agree(\%) }\end{array}$ & $\begin{array}{l}\text { Mann-Whitney U } \\
\text { test (p-value) }\end{array}$ \\
\hline $\begin{array}{l}\text { Using the cadavers instead of } \\
\text { dummies? }\end{array}$ & $\begin{array}{l}\text { Blended } \\
\text { Internet }\end{array}$ & $\begin{array}{l}3.5 \\
0\end{array}$ & $\begin{array}{l}9.5 \\
5.7\end{array}$ & $\begin{array}{l}14.5 \\
18.1\end{array}$ & $\begin{array}{l}44.5 \\
24.8\end{array}$ & $\begin{array}{l}28 \\
51.4\end{array}$ & $0.001^{*}$ \\
\hline $\begin{array}{l}\text { Adding application and YouTube } \\
\text { movies? }\end{array}$ & $\begin{array}{l}\text { Blended } \\
\text { Internet }\end{array}$ & $\begin{array}{l}3.5 \\
1\end{array}$ & $\begin{array}{l}3.5 \\
2\end{array}$ & $\begin{array}{l}6.5 \\
2\end{array}$ & $\begin{array}{l}44.5 \\
32\end{array}$ & $\begin{array}{l}42 \\
68\end{array}$ & $0.0001^{*}$ \\
\hline $\begin{array}{l}\text { Weekly credit hours of the laboratory } \\
\text { is sufficient? }\end{array}$ & $\begin{array}{l}\text { Blended } \\
\text { Internet }\end{array}$ & $\begin{array}{l}8.5 \\
0\end{array}$ & $\begin{array}{l}37 \\
8.6\end{array}$ & $\begin{array}{l}28 \\
36.2\end{array}$ & $\begin{array}{l}23 \\
40\end{array}$ & $\begin{array}{l}3.5 \\
15.2\end{array}$ & $0.0001^{*}$ \\
\hline $\begin{array}{l}\text { Is course duration not sufficient to list } \\
\text { all the practical anatomy topics? }\end{array}$ & $\begin{array}{l}\text { Blended } \\
\text { Internet }\end{array}$ & $\begin{array}{l}8 \\
2.9\end{array}$ & $\begin{array}{l}37.5 \\
33.3\end{array}$ & $\begin{array}{l}28 \\
27.6\end{array}$ & $\begin{array}{l}23 \\
32.4\end{array}$ & $\begin{array}{l}3.5 \\
3.8\end{array}$ & $0.043^{*}$ \\
\hline $\begin{array}{l}\text { The teaching staff in the laboratory } \\
\text { covered the topics of the curriculum? }\end{array}$ & $\begin{array}{l}\text { Blended } \\
\text { Internet }\end{array}$ & $\begin{array}{l}5 \\
6.7\end{array}$ & $\begin{array}{l}21.5 \\
17.1\end{array}$ & $\begin{array}{l}30.5 \\
35.2\end{array}$ & $\begin{array}{l}35 \\
32.4\end{array}$ & $\begin{array}{l}8 \\
8.6\end{array}$ & 0.984 \\
\hline Depending on small teaching groups? & $\begin{array}{l}\text { Blended } \\
\text { Internet }\end{array}$ & $\begin{array}{l}4.5 \\
2.8\end{array}$ & $\begin{array}{l}8 \\
4.6\end{array}$ & $\begin{array}{l}13.5 \\
13\end{array}$ & $\begin{array}{l}49 \\
39.8\end{array}$ & $\begin{array}{l}25 \\
39.8\end{array}$ & $0.004^{*}$ \\
\hline
\end{tabular}


Limpach et al. (2008) suggested that both on-campus and distance-learning students learned effectively [18]; however, our results differed. On-campus students ought to perform better, which may relate to more robust interaction at the nonvirtual teaching environment within the classroom between students and the teaching staff. Further, Ngan et al. (2018) claimed that students' affinity for BL is analogous to those reported in our results [17]. The heterogeneity of results among studies might relate to an abundance of factors, including the study design, the internal and external validity, and data analytics' reliability or interpretations.

Table 3: Third section of the survey: Questions with specific answers

\begin{tabular}{llll}
\hline Question & Blended group (\%) & Internet group (\%) & $\begin{array}{l}\text { Mann-Whitney U } \\
\text { test (p-value) }\end{array}$ \\
\hline $\begin{array}{l}\text { Which topic } \\
\text { was more }\end{array}$ & Cardiovascular (32.8) & Cardiovascular (38.1) & 0.068 \\
interesting? & Gervous (11) & Nervous (36.2) & \\
& Urogenitest (19.5) & Gastrointestinal (15.2) & \\
& Others (15.1) & Others (8.6) & \\
How many & One course (18.5) & One course (11.5) & 0.789 \\
courses are & Two courses (44.5) & Two courses (58.1) & \\
needed for & Three courses (20.5) & Three courses (19) & \\
the anatomy & Four courses (16.5) & Four courses (11.3) & \\
subject? & & & \\
\hline
\end{tabular}

IBL students showed higher scores in theory exams, which agrees with Zand et al. (2016), who claimed that Internet-associated technologies effectively improved the knowledge of anatomical sciences [21]. Regarding the survey on practical anatomy, participants preferred practical training on a cadaver, which is in unison with Kang et al. (2012), who advised using tasks related to cadaver dissection, especially in integrated learning [22]. Artificial dummies had a limited role in learning, although teachers implement these in most pharmacy colleges in Iraq.

Table 4: Final marks comparison: Blended vs. internet learning group

\begin{tabular}{llcc}
\hline $\begin{array}{l}\text { Element of } \\
\text { anatomy course }\end{array}$ & Group & $\begin{array}{c}\text { Mean } \\
( \pm \text { Std. Deviation) }\end{array}$ & $\begin{array}{c}\text { Student's t-test } \\
\text { (p-value) }\end{array}$ \\
\hline Marks (Practical) & Blended & $74.7( \pm 9.7)$ & 0.881 \\
Marks (Theoretical) & Internet & $65.5( \pm 9.7)$ & \\
& Blended & $66.2( \pm 8.8)$ & $0.011^{*}$ \\
& Internet & $72.1( \pm 10.9)$ & \\
\hline${ }^{*}$ Significant $P$ values are marked with an asterisk. &
\end{tabular}

Darras et al. (2019) concluded that using computer-based and mobile-based applications, rendering virtual and realistic anatomical dissection movies, had high acceptance among students and had improved cadaveric dissection skills [23]. Nevertheless, Saltarelli et al. (2014) required a careful alignment of learning tasks versus performance measures and meticulous monitoring of the transition between

Table 5: Blended versus IBL comparison

\begin{tabular}{|c|c|}
\hline BL & IBL \\
\hline Needed longer course duration & The course duration was enough \\
\hline $\begin{array}{l}\text { Preferred by students, especially for the } \\
\text { practical part }\end{array}$ & $\begin{array}{l}\text { BL is preferred, although IBL offered enough } \\
\text { time for studying; still, the practical part was } \\
\text { weak }\end{array}$ \\
\hline $\begin{array}{l}\text { Needed more weekly hours for the } \\
\text { laboratory }\end{array}$ & Online laboratory weekly hours were enough \\
\hline Higher marks in the practical part & Higher marks in the theoretical part \\
\hline $\begin{array}{l}\text { Preferred to study anatomy in two } \\
\text { courses }\end{array}$ & Same \\
\hline $\begin{array}{l}\text { The most exciting subject for students } \\
\text { was cardiovascular system }\end{array}$ & Same \\
\hline
\end{tabular}

simulated and cadaveric dependence in anatomical science education [24].

Our study showed that the highest percentage of BL students found that weekly credit hours for practical learning were insufficient to comprehend the subject of anatomy thoroughly and that they needed more time to correlate practical and theoretical knowledge. However, students from the IBL group opinionated differently; they declared that the weekly practical session was satisfactory, which might be attributed to the efficient self-management and allocation of time when studying via the Internet. Further, the highest percentage of both groups' participants revealed that teaching staff in the laboratory covered all the curriculum topics; still, students, in their notes, suggested prolonging the time for the laboratory to get maximum benefit. Concerning the small-group teaching in the laboratory, both groups were equally satisfied. In small-group teaching, the teaching staff can exercise more control, test the acquired information, diagnose defects in the learning process, and focus on subjects that mandate re-explanation or better interaction.

Participants of both groups were more interested in studying the cardiovascular system than others; perhaps, due to the widespread cardiovascular diseases in the community and other factors related to the ease of comprehension and visual appreciation of the cardiovascular system itself. In 2020, Mustafa and fellow researchers also confirmed the role of animated visual aids, specifically YouTube educational videos, including recorded lectures and tutorials, to enhance their students' learning experience, which agrees with our results [25]. A recent study also conveyed similar findings among postgraduate students [26]. On the other hand, the highest percentage of both groups suggested dividing the current anatomy syllabus to comprehend demanding subjects of human anatomy, including neuroanatomy and anatomy of the urogenital system, to secure more time for the learning process.

Concerning the practical knowledge of anatomy, our students had better marks when enrolled in the BL group, which is in unison with Singh et al. (2019), who claimed that students should have appropriate practical training to appreciate musculoskeletal anatomy better [19]. Further, Zargaran et al. (2020) suggested that traditional cadaveric teaching still represents the cornerstone choice for medical students, while technological interventions, using internet videos and virtual dissection tools, should support cadaver-oriented teaching [27]. Estai and Bunt (2016) also suggested multimodal learning by implementing plastination and anatomy prosections for more efficient learning [28]. Nevertheless, earlier in 2009, Tam et al. claimed no evidence to verify that IBL could be an adequate substitute for the classical way of teaching human anatomy [29].

Our study has some limitations, including implementing a cross-sectional study design, the 
relatively small sample size, and the inherent limitations of statistical analysis [30], [31]. Cross-sectional surveys frequently suffer from nonresponse bias; nonetheless, we excluded missing data from our data analytics. Another form of bias in cross-sectional studies is the recall bias; the unintentional falsification of results is one of the crucial limitations of research conducted during a pandemic. Although we conducted the present study with the highest standards and methodological rigor, unconscious defense mechanisms, triggered in almost all people, may cause incorrect self-perception and, at the same time, inadequate evaluation of the acquired skills. Future research requires larger samples, evaluating the heterogeneity among populations of interest, including pharmacy students and (para)medical students. Studies should aim for robust evidence by exploring longitudinal study designs, controlled trials, systematic reviews, and meta-analytic while deploying robust data analysis tools and methods [32], [33], [34].

Preparing pharmacy students for their future duties is a highly responsible task for teachers and students studying in this field. Thanks to high requirements, observed especially during direct contact (practical classes) between lecturers and students, it is possible to maintain a high level of education necessary to perform medical professions properly. Unfortunately, during the pandemic, practical classes at many universities were reduced to the necessary minimum or replaced by online learning. At the same time, the increase in negative consequences of the coronavirus pandemic (infections and deaths), caused a state of permanent tension in people [35], which in turn, as mentioned earlier, can lead to anomie [10].

With the development and growth of pandemics, several confirmatory research of human anomic states surfaced [36], [37]. The mental condition of the global community has deteriorated, as confirmed by numerous studies, for example, by Javed et al. (2020), Xiong et al. (2020), Khan et al. (2021), and Passavanti et al. (2021) [35], [38], [39], [40]. The extent to which the new pandemic circumstances may have affected students' self-assessment of the knowledge they acquired by learning almost exclusively online during the collective trauma (conditions unbearable for everyone, therefore for them too) needs meticulous scrutiny. Therefore, it is imperative to help people restore the necessary well-being in the new post-pandemic reality (both improved physical and psychological well-being).

Finally, we opine that the current study will add to the cumulative knowledge of understanding, predicting, and managing the human resources for combating the pandemic and its adverse effects [41], [42]. As of August 8, 2021, SARS-CoV-2 infected 222,788,994 humans and claimed the lives of $4,600,327$, while in Iraq, it infected 1,928,930 and led to the death of 21,220 individuals. The novel coronavirus disease 2019 affected countries from developed and developing nations, including the United States, India,
Brazil, the United Kingdom, Russia, France, Turkey, Argentina, Iran, and Columbia [43]. Therefore, during the pandemic, humanity should strive at all frontiers, from vaccine and therapeutics development to enhancing teaching and educational methods, including medical education.

\section{Conclusions}

The anatomy course for pharmacy students needs to be revised periodically to ensure better learning outcomes for the main stakeholders in the educational process. Our study elucidated the positive and negative aspects of IBL and $B L$. The students favored BL. However, BL students mandated a longer course duration, needed more weekly hours for the practical teaching, preferred to study anatomy in two courses, and found the cardiovascular system was the most interesting to study. Overall, Iraqi undergraduate pharmacy students favored BL, which may relate to the nonvirtual (live) interaction between the students and the teachers, and the distinct practical training method. Therefore, we conclude that internet resources can be used as collateral modalities for studying human anatomy but not as substitutes.

\section{Contribution of Authors}

SSF developed the study concept, reviewed the literature, and wrote the first draft of the manuscript. AA developed the discussion section, conducted proofreading, enhanced the scholarly presentation of the article, and revised the final version of the manuscript. MAM contributed to developing the introduction and the discussion sections of the article.

\section{References}

1. Guimarães B, Dourado L, Tsisar S, Diniz JM, Madeira MD, Ferreira MA. Rethinking anatomy: How to overcome challenges of medical Education's evolution. Acta Med Port. 2017;30(2):134- 40. https://doi.org/10.20344/amp.8404 PMid:28527481

2. Jamie K. The pharmacy gaze: Bodies in pharmacy practice. Sociol Health IIIn. 2014;36(8):1141-55. https://doi. org/10.1111/1467-9566.12157 PMid:25091983

3. Boyce EG, Lawson LA. Preprofessional curriculum in preparation for doctor of pharmacy educational programs. Am J Pharm 
Educ. 2009;73(8):155. https://doi.org/10.5688/aj7308155 PMid:20221348

4. Rathbone A, Nazar H, Harburn J, Todd A, Husband AK. Exploring undergraduate pharmacy student experiences of learning human anatomy using cadaveric specimens. Am J Pharm Educ. 2019;83(8):7103. https://doi.org/10.5688/ajpe7103

PMid:31831899

5. Majumder MA. Issues and priorities of medical education research in Asia. Ann Acad Med Singap. 2004;33(2):257-63. PMid:15098645

6. Brisbourne MA, Chin SS, Melnyk E, Begg DA. Using web-based animations to teach histology. Anat Rec. 2002;269(1):11-9. https://doi.org/10.1002/ar.10054

PMid:11891621

7. Garrett BM, Callear D. The value of intelligent multimedia simulation for teaching clinical decision-making skills. Nurse Educ Today. 2001;21(5):382-90. https://doi.org/10.1054/ nedt.2001.0568

PMid: 11403585

8. Granger NA, Calleson DC, Henson OW, Juliano E, Wineski L, Mcdaniel MD, et al. Use of web-based materials to enhance anatomy instruction in the health sciences. Anat Rec B New Anat. 2006;289(4):121-7. https://doi.org/10.1002/ar.b.20104

PMid: 16865700

9. Rizzolo LJ, Aden M, Stewart WB. Correlation of web usage and exam performance in a human anatomy and development course. Clin Anat. 2002;15(5):351-5. https://doi.org/10.1002/ ca. 10045

PMid:12203379

10. Motyka MA, Al-Imam A, Aljarshawi MH. SARS-CoV-2 pandemic as an anomie. Przestrzeń Społeczna. 2020;20:111-44.

11. Merton RK. Social Structure and Anomie. United Kingdom: Routledge; 2017. p. 3-13.

12. Teymoori A, Jetten J, Bastian B, Ariyanto A, Autin F, Ayub N, et al. Revisiting the measurement of anomie. PLoS One. 2016;11(7):e0158370.

PMid:27383133

13. Rao $\mathrm{KH}$, Rao RH. Perspectives in medical education 8. Enhancing preclinical education in Japan with a clinically focused, interactive anatomy curriculum. Keio $\mathrm{J}$ Med. 2009;58(4):210-5.

PMid:20037284

14. Snelgrove H, Familiari G, Gallo P, Gaudio E, Lenzi A, Ziparo V, et al. The challenge of reform: 10 years of curricula change in Italian medical schools. Med Teach. 2009;31(12):1047-55. https://doi.org/10.3109/01421590903178506

PMid:19995166

15. Edgren G, Haffling AC, Jakobsson UL, Mcaleer S, Danielsen N. Comparing the educational environment (as measured by DREEM) at two different stages of curriculum reform. Med Teach. 2010;32(6):e233-8. https://doi. org/10.3109/01421591003706282

PMid:20515368

16. Kim KJ, Kee C. Reform of medical education in Korea. Med Teach. 2010;32(2):113-7.

PMid:20163225

17. Ngan OM, Tang TL, Chan AK, Chen DM, Tang MK. Blended learning in anatomy teaching for non-medical students: An innovative approach to the health professions education. Health Prof Educ. 2018;4(2):149-58. https://doi.org/10.1016/j. hpe.2017.11.001

18. Limpach AL, Bazrafshan P, Turner PD, Monaghan MS. Effectiveness of human anatomy education for pharmacy students via the internet. Am J Pharm Educ. 2008;72(6):145. https://doi.org/10.5688/aj7206145

PMid:19325961

19. Hoffmann D, Swailes N. GRISTO: An integrated learning experience in gross anatomy and histology for dental students, learning outcomes and student perspectives on curriculum change (532.4). FASEB J. 2014;28:532-4. https://doi. org/10.1096/fasebj.28.1_supplement.532.4

20. Singh K, Bharatha A, Sa B, Adams OP, Majumder MA. Teaching anatomy using an active and engaging learning strategy. BMC Med Educ. 2019;19(1):1-8. https://doi.org/10.1186/ s12909-019-1590-2

21. Zand A, Abbaszadeh HA, Abdolahifar M, Aghaee AA, Amini A, Mastery FR. Role of E-learning in teaching anatomical sciences. Anat Sci. 2016;13(1):55-60.

22. Kang SH, Shin JS, Hwang YI. The use of specially designed tasks to enhance student interest in the cadaver dissection laboratory. Anat Sci Educ. 2012;5(2):76-82. https://doi. org/10.1002/ase.1251

PMid:22143981

23. Darras KE, Spouge R, Hatala R, Nicolaou S, Hu J, Worthington A, et al. Integrated virtual and cadaveric dissection laboratories enhance first year medical students' anatomy experience: A pilot study. BMC Med Educ. 2019;19(1):366. https://doi.org/10.1186/ s12909-019-1806-5

PMid:31590672

24. Saltarelli AJ, Roseth CJ, Saltarelli WA. Human cadavers vs. multimedia simulation: A study of student learning in anatomy. Anat Sci Educ. 2014;7(5):331-9. https://doi.org/10.1002/ ase. 1429 PMid:24415563

25. Mustafa AG, Taha NR, Alshboul OA, Alsalem M, Malki ME. Using YouTube to learn anatomy: Perspectives of Jordanian medical students. Biomed Res Int. 2020;2020:6861416. https:// doi.org/10.1155/2020/6861416

PMid:32337267

26. Kelsey AH, McCulloch V, Gillingwater TH, Findlater GS, Paxton JZ. Anatomical sciences at the University of Edinburgh: Initial experiences of teaching anatomy online. Transl Res Anat. 2020;19:100065. https://doi.org/10.1016/j.tria.2020.100065

27. Zargaran A, Turki MA, Bhaskar J, Spiers HV, Zargaran D. The role of technology in anatomy teaching: Striking the right balance. Adv Med Educ Pract. 2020;11:259-66. https://doi. org/10.2147/amep.s240150 PMid:32280294

28. Estai M, Bunt S. Best teaching practices in anatomy education: A critical review. Anna Anat. 2016;208:151-7. https://doi. org/10.1016/j.aanat.2016.02.010

PMid:26996541

29. Tam MD, Hart AR, Williams S, Heylings D, Leinster S. Is learning anatomy facilitated by computer-aided learning? A review of the literature. Med Teach. 2009;31(9):e393-6. https:// doi.org/10.1080/01421590802650092

PMid:19811174

30. Al-Imam A, Sahai A, Al-Derzi AR, Al-Shalchy A, Abdullah F. All models are wrong, but some are useful: On the non-bayesian statistical robustness of Hilton's law. Eur J Anat. 2020;24(1):75-8.

31. Al-Imam A, Abdul-Wahaab IT, Konuri VK, Sahai A, Al-Shalchy AK. Unification of frequentist inference and machine learning for pterygomaxillary morphometrics. Folia Morphol. 2021;80(3):625-41. https://doi.org/10.5603/fm.a2020.0149

32. Al-Imam A. Optimizing linear models via sinusoidal transformation for boosted machine learning in medicine. J Fac Med Baghdad. 2019;61(3-4):128-36.

33. Al-Imam A. A novel method for computationally efficacious linear and polynomial regression analytics of big data in medicine. Mod 
Appl Sci. 2020;14(5):1-10. https://doi.org/10.5539/mas.v14n5p1

34. University of Oxford. The Centre for Evidence-Based Medicine; 2021. Available from: https://www.cebm.net. [Last accessed on 2021 Apr 25].

35. Xiong J, Lipsitz O, Nasri F, Lui LM, Gill H, Phan L, et al. Impact of COVID-19 pandemic on mental health in the general population: A systematic review. J Affect Disord. 2020;277:55-64. https:// doi.org/10.1016/j.jad.2020.08.001

PMid:32799105

36. Kene P. Mental health implications of the COVID-19 pandemic in India. Psychol Trauma. 2020;12(6):585-7. PMid:32757578

37. Miller JM, Blumstein A. Crime, justice and the COVID- 19 pandemic: Toward a national research agenda. Am J Crim Justice. 2020;45(4):515-24. https://doi.org/10.1007/ s12103-020-09555-z

38. Javed B, Sarwer A, Soto EB, Mashwani ZU. The Coronavirus (COVID-19) pandemic's impact on mental health. Int J Health Plann Manage. 2020;35(5):993-6. https://doi.org/10.1002/ hpm.3008

PMid:32567725
39. Khan S, Siddique R, Xiaoyan W, Zhang R, Nabi G, Afzal MS et al. Mental health consequences of infections by coronaviruses including severe acute respiratory syndrome Coronavirus 2 (SARS-CoV-2). Brain Behav. 2021;11(2):e01901. https://doi. org/10.1002/brb3.1901/v2/response1

PMid:33314732

40. Passavanti M, Argentieri A, Barbieri DM, Lou B, Wijayaratna K, Mirhosseini AS, et al. The psychological impact of COVID19 and restrictive measures in the world. J Affect Disord. 2021;283:36- 51. https://doi.org/10.1016/j.jad.2021.01.020 PMid:33516085

41. Al-Imam A, Khalid U, Al-Doori HJ. Predictive epidemiology for SARS-CoV-2 pandemic in Iraq. Asian $J$ Med Sci. 2021;12(3):121- 4. https://doi.org/10.3126/ajms.v12i3.33402

42. Al-Imam A, Khalid U, Al-Doori HJ. Clustering analysis of Coronavirus disease 2019 pandemic. Asian J Med Sci. 2021;12(2):108-13.

43. Worldometer. COVID-19 Coronavirus Pandemic; 2021. Available from: https://www.worldometers.info/coronavirus. [Last accessed on 2021 Sep 08]. https://doi.org/10.3126/ajms. v12i2.33401 